\title{
Royal Photographic Society's Annual Exhibition
}

$\mathrm{T}$ HE eighty-third annual exhibition of the Royal Photographic Society at 35 Russell Square, London, will remain open until October 8.

Several photographs are shown of the tracks formed by elementary particles ejected by disrupting atoms embedded in the emulsion. The spacing of the grains in a track is characteristic of the particle and its energy. Among the examples shown are the tracks of $\alpha$-particles ejected by cosmic rays and neutrons, the $\alpha$-particles from thorium $\mathrm{C}^{\prime}$ and tracks due to protons and deuterons. Another interesting photograph shows the identification of the radioactive isotope of samarium from the direct deposits of the isotopes by a mass-spectrograph on the photographic emulsion. Short tracks are to be seen under the isotope of mass 148 .

The recent theory of latent image formation by Gurney and Mott is illustrated by a series of diagrams representing the electronic and ionic processes involved. Of particular interest is the photograph showing the destruction by red light of the unformed latent image at low temperatures, thus demonstrating the existence of trapped electrons.

A series of ripple tank photographs illustrates the diffraction and interference effects of waves, and some direct photographs of optical interference fringes are designed to show the variation of fringe width with colour. Two photographs demonstrate a method of estimating the amount of odoriferous vapour given off by a flower by comparing its action with that of camphor vapour on the appearance of a talc-covered pool of mercury as a monomolecular layer of the vapour forms on its surface.
One of the most interesting exhibits is a 15-ft. solar spectrum taken on Kodachrome film at the Mount Wilson Observatory. Other astronomical exhibits include photographs of the sun's corona and prominences taken during the total eclipse of June 8, 1937. A number of very fine eloud photographs show the formation of thunderclouds and the appearance of a line squall.

The use of photography in aerial survey is illustrated by photographs taken with a nine-lens air camera which covers up to 300 square miles at one exposure. Another aerial photograph shows the presence of archæological remains by faint markings in the soil which may be quite indistinguishable to an observer on the ground. Some high-speed photographs are on view, one of a revolver firing taken at an exposure of two millionths of a second.

A series of twenty-two wedge spectrograms exhibited by Ilford Limited show that it is possible to sensitize emulsions in any selected region over a considerable range of the spectrum. Kodak Limited have an interesting exhibit showing the image of a spectrum on Kodachrome film at each stage of the processing. Another exhibit shows the technical basis of the Kodak wash-off relief colour printing process.

The exhibition also includes a number of photomicrographs of biological, botanical and metallurgical subjects, and others demonstrating the value of photomicrography in the detection of forgeries and other criminal investigations. The radiographs cover a wide range of subject types, but there is an unfortunate lack of technical data. New photographic apparatus is on view in various parts of the exhibition.

\section{Decapod Larvæ of the Great Barrier Reef*}

$\mathrm{D}^{\mathrm{n}}$ R. GURNEY describes some very interesting larvæ in his latest work. The life-histories of the Palæmonidæe are little known except for certain members of the Palæmoninæ, and a large series of larvæ from the Great Barrier Reef together with material from Ghardaqa on the Red Sea and from the "Discovery" Expedition has enabled the author to make a decided increase in our knowledge of the group, which is a difficult one.

Among the Palæmonids are specimens belonging to Ortmann's larval genus Retrocaris, of very large size, and the study of these leads to the conclusion that the larvæ of the Retrocaris group belong to the genus Palaemon or the closely related Brachycarpus, which, although the adults inhabit fresh water, may in certain species migrate to the sea to liberate their larvæ. A summary is given of the characters of the last larvæ of Leander (excluding $L$. tenuicornis, which differs conspicuously and should possibly be placed in a separate genus) and of Retrocaris (Palaemon or Bruchycarpus). The larval Pontoniinæ in the collections belong to two groups, one of which, the Periclimenes group, is easily defined and a fair amount is known about them. It is exceedingly interesting, however, that the larvæ of Periclimenes diversipes and Harpilius gerlachei indicate quite a different generic grouping of the adults from that which is adopted by Kemp. A study of the adults apparently bears this out, $P$. diversipes differing from Periclimenes grandis, $P$. agag and $P$. americanus in almost every appendage and resembling Harpilius or Coralliocaris. Larvæ of the Mesocaris group of the Pontoniinæ are much more difficult to classify. The new name Cryptoleander has been coined for a third group including three peculiar larvæ. Anchistoides also has very distinct features, and the late larvæ almost certainly belonging to this genus are most striking. It is suggested that it should not be placed in the Pontoniinæ but in a distinct subfamily.

The Alpheidæ show as a rule great uniformity of structure in the larvæ, several of which are described. Their main interest lies in the apparently close rela. tionship with the Palæmonidæ. Hitherto there has been a tendency to regard this family as more nearly related to the Hippolytidæ, but the discussion at the end of this paper shows that the Alpheid and Palæmonid larvæ agree in many characters, well shown in the present material. The fact that a species of Coralliocaris was found which snapped its claws like an Alpheid is significant.

* The Larvæ of the Decapod Crustacea. Palæmonidæ and Alpheidæ. By Dr. Robert Gurney. (Great Barrier Reef Expedition 1928-29. Scientific Reports, 6, No. 1). (London: British Museum (Naturai History), 1938). 